D0I: https://doi.org/10.31874/2309-1606-2021-27-1-10

удК 1(371.3:303.093.3)

\title{
Ірина Добронравова
}

\section{Автопоезис в онлайн навчанні}

Концепція автопоезису займає важливе місце серед концепцій самоорганізації. Біологи Умберто Матурана і Франсіско Варела розглядають живі істоти як такі, що само-будують та само-конструюють себе, тобто як автопоетичні системи. Вони проголосили: «Усяка дія $є$ пізнання, усяке пізнання $\epsilon$ дія» в своїи відомій книзі «Древо пізнан-

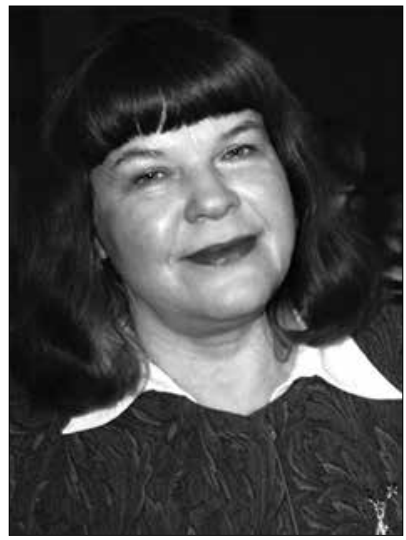
ня». Це стосується всіх живих істот включно з людськими істотами, що мають біологічне коріння свого пізнання. Авторка цієї статі обрала концепцію автопоезису в якості робочої моделі онлайн навчання, тому що воно позбавлено такого біологічного коріння в онлайн комунікації. Неусвідомлені, але впливові риси живого спілкування людей з їх «втіленим розумом» якраз і втрачаються при онлайн спілкуванні. Аналізуючи власний досвід офлайн та онлайн викладання в рамках авто поетичного підходу, авторка намагається шукати засоби подолання обмежень онлайн викладання та навчання. Ідея Матурани та Варели про постійні рекурентні взаємодії між учасниками пізнання та дії, які забезпечують створення ними спільного світу у спільному лінгвістичному полі стала вихідним пунктом подальших висновків. Активна комунікація між викладачем та студентами та студентів між собою може частково компенсувати відсутність живого спілкування. Концепція автопоезису здатна максимально сприяти спілкуванню викладачів і студентів та студентів між собою, щоб забезпечити зворотні зв'язки у сумісних діях пізнання, створюючи ефект стійкої самоорганізації у навчанні.

Ключові слова: автопоезис, онлайн навчання, самоорганізація, комунікація, само-конструювання, рекурентні взаємодії.

Серед теорій самоорганізації складних систем важливе місце займає концепція автопоезису, сформульована біологами Франсіско Варела та Умберто Матурана. У цьому дописі я використаю цю концепцію в якості робочої моделі для усвідомлення досвіду онлайн навчання, який нам усім довелось набути в ситуації пандемії 2020 року. А оскільки і в пост-пандемічній ситуації практики онлайн навчання будуть продовжувати застосовуватись, хоча й наряду з іншими, більш традиційними навчальними практиками, розуміння місця самоорганізації у процесі навчання не завадить і надалі.

(C) I. Добронравова, 2021 
Справа в тому, що намагання перенести в онлайн навчання стандартні звичні практики навчальної роботи виглядають за моїми враженнями так само "вдало», як перші автомобілі, що нагадували карети без коней, або як перші фільми, в яких просто знімали театральні вистави. Так, наприклад, в пошуках досвіду організації тестів або іспитів я натрапляла на такі варіанти боротьби зі списуванням: давати одне питання за іншим якомога швидше. Зрозуміло, що докорінна зміна навчальної ситуації викидає нас усіх на границі габітусу, тобто звичних і багато в чому неусвідомлюваних практик. [Бурд'є 2003]. Та вихід на ці границі вимагає не судомного тримання за ті практики, а рефлексії над ними.

Я вже мала нагоду писати [Добронравова 2005] про те, наскільки недоречним і неадекватним $€$ досі широко розповсюджене уявлення про навчання, засноване на класичному ідеалі раціональності [Мамардашвілі 1994]. Ось як характеризує це класичне розуміння сам Мамардашвілі: «В класичній педагогіці, а вона лише окремий елемент загального класичного стилю мислення, фактично передбачається деяка привілейована (і в цьому сенсі одна єдина і абсолютна) система відліку - така, що перенос знання ... з однієї голови до іншої в навчанні і засвоєнні... грунтується на реконструкції або відтворенні одного єдиного суб'єкта по всіх точках... Ми вважаємо, що процес навчання полягає в тому, що якщо, наприклад, дитина знаходиться в точці А і у мене, універсального спостерігача, $є$ знання про те, що відбувається в точці А, я можу передати дитині це знання» [Мамардашвілі 1994: 12-13]. А далі Мамардашвілі пише про те, що весь досвід педагогіки, психології, лінгвістики спростовує це спрощене класичне розуміння.

На жаль, інституціональні освітні традиції сильніші за цей досвід, навіть коли він схвалюється та пропагується. Так, у закладах вищої освіти і досі педагогічне навантаження регламентується і рахується за схемою кількості аудиторних годин, лекційних та семінарських. При цьому критерії оцінки прописані таким чином, що самостійна робота студентів має складати основу такої оцінки. Але перевірка цих самостійних робіт взагалі в педагогічному навантаженні не передбачена. Так що педагоги сприяють самостійній роботі студентів на волонтерських засадах.

Усвідомлення важливості самостійної роботи в навчанні підкріплюється і теоріями самоорганізації, зокрема, синергетики [Добронравова 2017: 273-282]. Думка про те, що, навчаючись, людина створює саму себе, долучаючись до культурних надбань людства, і що відповідні зусилля найкраще забезпечуються створенням умов процесу самоорганізації як сумісної дії викладача та студентів, вчителя та учнів, добре підкріплюється синергетичними моделями. При цьому завдяки трансдисциплінарності синергетики здійснюється співробітництво природничників та гуманітаріїв у вивченні людини. 
Мені запам'яталась міжнародна конференція з нелінійної науки, присвячена синергетичним дослідженням та їх застосуванню в науках про живе. Серед різноманітних секцій конференції була й секція, присвячена використанню нелінійних методів в освіті. Пошлюсь для прикладу на доповідь з характерною назвою «Хаос в класній кімнаті» [Davis-Seaver 2003]. Автор розглядав стратегію викладача по створенню в аудиторії передумов для дискусії за рахунок формулювання у якості атракторів альтернативних варіантів відповідей на питання, що обговорюється. Конкуренція цих атракторів в середовищі вільної полеміки створює нелінійну хаотичну динаміку, особливу в кожному з навчальних колективів, стимулюючи інтерес учнів. Я перевіряла цю стратегію у роботі зі студентами та аспірантами. Вона працює, принаймні при безпосередній комунікації в аудиторії.

Питання полягає саме в тому, чи розуміємо ми, як саме безпосередня комунікація в аудиторії неявним чином спрацьовує в навчальному процесі. Як харизма викладача, емпатія учнів, стан настроїв в студентському колективі з формальними і неформальними лідерами та зірками цієї соціальної групи впливають на пізнавальні процеси тих, хто навчається і на роботу того, хто навчає? Усвідомивши значення таких впливів, можна буде шукати способи компенсації їх відсутності при навчанні онлайн. Мова йде про усвідомлення як концептуалізацію того відчуття незадоволення викладачів, особливо лекторів, яке є загальним враженням від роботи онлайн. Саме в контексті цієї проблеми стає зрозумілим звернення саме до концепції автопоезису, оскільки моменти втіленості розуму (embodied mind) $\epsilon$ центральними в цій концепції.

Вихідна теза $Ф$ Варела і У. Матурана проголошується ними на самому початку їх відомої книги «Древо пізнання». Вона така: «Усяка дія $\epsilon$ пізнання, усяке пізнання є дія» [Варела, \& Матурана 2001: 23]. 3 цим афоризмом тісно пов'язана конструктивістська настанова авторів, висловлена на тій же сторінці: «Це замкнене коло, цей взаємозв'язок між дією і досвідом, ця нероздільність конкретного способу існування і того, яким чином світ предстає перед нами, свідчать, що кожен акт пізнання породжує деякий світ» [Варела, \& Матурана 2001: 23].

Щодо визначення поняття автопоезису, наведу найбільш характерний вислів:

«Механізм, що перетворює живі істоти на автономні організми - це автопоезис» [Варела, \& Матурана 2001: 42]. Не зупиняючись докладно на розгляді біологічної частини «древа пізнання», поглянемо на специфіку розуміння власне людського пізнання в концепції автопоезису. Отже, «..людське пізнання як ефективна дія належить біологічній царині, але завжди проживається в певній культурній традиції» [Варела, \& Матурана 2001: 215]. При цьому автори концепції автопоезису наго- 
лошують на неусвідомленості традиційних дій: «Уся сукупність регулярностей, притаманних спряженню тієї чи іншої соціальної групи, $\epsilon$ ії біологічною та культурною традицією. А традиція - це не тільки спосіб бачити і діяти, але й спосіб приховувати та втаємничувати. Традиція включає в себе всі варіанти соціальної поведінки, які в історії соціальної системи стали очевидними, регулярними і прийнятними. Оскільки всі ці варіанти не потребують роздумів для свого здійснення, вони залишаються невидимими, поки не стають неприйнятними. I саме тоді у гру вступає рефлексія» [Варела, \& Матурана 2001: 214-215].

Що ж саме дає концепція автопоезису для здійснення такої рефлексії над навчальним процесом в ситуації онлайн навчання? Мені здається, що вирішальною тут $є$ думка про необхідність постійної рекурентності взаємодій людей для вироблення ними спільного світу. «В потоці регулярних рекурентних взаємодій мова з'являється, коли операції в лінгвістичному полі призводять до координації дій щодо дій, що належать самій лінгвістичній царині» [Варела, \& Матурана 2001: 185] Тобто для координації дій потрібна постійна рекурсія:«мова як явище реалізується в рекурсії лінгвістичних координацій дій. Тим самим лінгвістичне поле стає частиною довкілля, в якому відбувається лінгвістична координація дій» [Варела, \& Матурана 2001: 186].

Одразу зазначимо, що рекурсія, тобто постійний зворотній зв'язок між лектором і аудиторією в ситуації онлайн читання лекції надзвичайно утруднений. В безпосередній комунікації лектор одразу бачить реакцію аудиторії, $є$ ознаки нерозуміння або втоми, питання лектора до аудиторії та слухачів до лектора виникають і озвучуються швидше. Звичайно, для нерішучих, невпевнених у собі студентів виголосити питання посеред аудиторії, можливо, і складніше, ніж написати його в чаті. Але час на написання та прочитання питання відтерміновує відповідь та може порушити логіку викладу. Я як лектор надаю перевагу питанням, виголошеним вголос, бо тоді всі слухачі залучені до дискурсу. Крім усього іншого, завжди цікаво, чи здатний лектор швидко і вичерпно відповісти на питання, особливо, якщо мова йде про перші лекції, коли лектор ще не зарекомендував себе перед аудиторією. На щастя, досить часто один чи два рішучих чи зацікавлених слухачів трапляються в аудиторії, особливо на старших курсах, і їхні питання оживляють перебіг лекції навіть в онлайн режимі.

На мій погляд, важливо розуміти, що автопоезис як самоорганізація стосується не окремо студентів чи викладачів. Автопоезисом може і має бути самоорганізація лінгвістичного поля як середовища, в якому можлива координація дій, що забезпечує виникнення смислу, бо «смисл виникає при цьому як відношення лінгвістичних різниць, і смисл стає частиною нашої області збереження адаптації» [Варела, \& Матурана 2001: 186]. 
Особливо важливе встановлення відношення і кореляції лінгвістичних різниць при викладанні загальноосвітніх дисциплін гуманітарного профілю студентам природничих або інженерних спеціальностей. Далеко не завжди тут можна спертись на певний загальний культурний фон для встановлення взаєморозуміння. Ситуацію при онлайн навчанні полегшує невелика кількість студентів в групі. Принаймні частину облич можна бачити на екрані та реагувати на їх вираз, хоча, звичайно, ніщо не може замінити того стану єднання з аудиторією, якого вдається іноді досягнути, коли розповідаєш небайдужі для тебе речі небайдужим до них людям. Це як раз те, що в постнекласичному типі наукової раціональності називають людино вимірними системами і ціннісною забарвленістю їх пізнання [Степин 2000]. І знову ж таки, взаємний вплив слухачів одне на одного, як і підсилення спільних настроїв за рахунок безпосередньої взаємодії компенсувати в онлайн навчанні дуже проблематично.

Серед переваг онлайн навчання зазначають зручність демонстрації презентацій, так звану наочність. Дійсно, тут вже не залежиш від надто «скромної» оснащеності аудиторій проекторами. Та наочність показана не всім дисциплінам. За моїм багаторічним досвідом, абстрактним міркуванням наочність може і заважати. Ніщо так не збиває слідкування за думкою філософа, ніж споглядання його портрету. Хоча при викладанні філософії науки, коли знайомиш людей з досягненнями сучасної наукової революції, ілюстрація принципової процесуальності нелінійної динаміки за рахунок демонстрації на екрані процесів самоорганізації фракталів дуже допомагає. Допомагає, але не замінює подадьшого осмислення такої процесуальності.

Складно не погодитись з Матурано і Варелою в тому, що «тільки коли структурна спряженість деяких сторін нашого існування спотворюється, ми починаємо розуміти, до якого ступеню наші поведінкові координації в маніпулюванні оточуючим світом і комунікація невіддільні від нашого життєвого досвіду» [Варела, \& Матурана 2001: 206]. Отже, потрібно змінювати життєвий досвід, адже він проходить у відповідності 3 «когерентністю у повсякденному житті того невпинного потоку рефлексій, який ми називаємо свідомістю та асоціюємо з нашою індивідуальністю» [Варела, \& Матурана 2001: 204]. 3 іншого боку, «наш життєвий досвід протікає у відповідності з когерентністю у функціонуванні нашої нервової системи, до якої ми як спостерігачі не маємо доступу, але яка обов'язково має місце як частина нашого онтогенетичного дрейфу в якості живих систем» [Варела, \& Матурана 2001: 204].

Отже, питання полягає в тому, як випрацювати у новій ситуації такий життєвий досвід, який забезпечить відповідну когерентність індивідуальностей, залучених у навчальний процес, сподіваючись і на станов- 
лення відповідної когерентності у функціонуванні нас як живих систем. При цьому треба зважати на те, що життєвий досвід викладачів та учнів щодо повсякденних звичок користування онлайн платформами може дуже різнитися, причому у студентів, він, як правило, більший , ніж у викладачів. Так, студенти легко користуються декількома платформами, орієнтуючись на ті, які спромоглись засвоїти різні викладачі.

Існує велика спокуса для викладачів обрати такий спосіб дії, який максимально дистанціює викладача від студента: відеозапис лекцій, максимально формалізовані тести, письмовий іспит - всі ці форми роботи, здавалося б, сприяють максимальній об'єктивності та перевірюваності оцінок та сприяють самостійності студентів в організації їх навчання. Та й нервова система викладача при цьому залишається ціліша. Але як раз застосування концепції автопоезису демонструє певну моральну незадовільність такого підходу до викладання. Ще раз пошлюсь на Варела та Матурану: «не враховувати тотожність пізнання та дії, не бачити, що пізнання $\epsilon$ дія, і не розуміти, що будь-який людський акт здійснюється в омовленості і як такий (як соціальний акт) має стосунок до етики, оскільки залучає людські якості - означає не бачити людину як живу сутність» [Варела, \& Матурана 2001: 218].

На що орієнтує студента або аспіранта така дистанційованість? Заробляти бали? Навіть, якщо студенти хочуть їх заробляти і не вважають обов'язкову, хоча не фахову для них загальноосвітню (гуманітарну) дисципліну потрібною, вони «олюднюють» стосунки з викладачем принаймні у листуванні. I не треба недооцінювати те, що багато з них цікавляться гуманітарними дисциплінами «для душі» (це вираз одного з моїх студентів - природничників). Не всі вони це розуміють чи визнають. Але моральне зобов'язання викладача, на мій погляд, сприяти спілкуванню студентів з викладачами, нехай і онлайн. Розмовляти з ними на лекціях і семінарах, коментувати їхні відповіді і презентації, і зрештою задати на іспиті питання по письмовій роботі, щоб з'ясувати, що вони зрозуміли, та щось на останок пояснити або прояснити.

Може здатись, що це моралізування гуманітаріїв. Але ще більшою мірою це стосується викладачів фахових кафедр. Недарма лабораторні роботи ніхто не відміняв. Згадайте книгу Майкла Полані «Особистісне знання» [Полані 1985], в якій він визначає роль зразка поведінки керівника у спільній роботі в лабораторії визначальним моментом у становленні нового спеціаліста.

Отже, основний мій висновок зі спроби застосування до онлайн навчання концепції автопоезису: остання здатна максимально сприяти спілкуванню викладачів і студентів та студентів між собою, щоб забезпечити зворотні зв'язки у сумісних діях пізнання. За неможливості збільшення аудиторних годин, дати викладачам можливість більш віль- 
но розпоряджатись «годинами» для організації роботи в межах курсу, сприяти роботі в малих групах (7-8 людей, нехай і паралельно) і взагалі перетворювати обмеження онлайн навчання на переваги онлайн технологій для самоорганізації спільного дієвого простору пізнання.

\section{Посилання:}

Бурд’є, П. (2003). Практичний глузд / Пер. з фр. О. Йосипенко, С. Йосипенка, А. Дондюка. За ред.С. Йосипенка. Київ: Український Центр духовної культури.

Варела, Ф., \& Матурана У. (2001). Древо познания: биологические корни человеческого понимания / пер. с англ. Ю.Данилова. М.: Прогресс - Традиция.

Добронравова, I. С. (2005). Філософія освіти за доби постнекласичної науки. Філософія освіти, (1), 116-125.

Добронравова, I. С. (2017) Практична філософія науки. Збірка наукових праць. Суми: Університетська книга.

Мамардашвили, М. К. (1984). Классический и неклассический идеалы рациональности. Тбилиси: Мцениереба.

Полани М. (1985). Личностное знание / пер. с англ..В.А.Лекторского, В.И.Аршинова. Москва: Прогресс.

Степин, В. С. (2000). Теоретическое знание. М.: Прогресс-Традиция

Davis-Seaver, J. (2003). Chaos in the Classroom. INSC 2003. Programme and Abstracts. (7-9 of February Vienna. Austria ), 42.

\section{References:}

Bourdieu, P. (2003). Practical Sens / transl. from French by O. Yosypemko, S. Yosypemko, \& A. Dondiuk; edit. by S. Yosypemko. Kyiv: Ukrainian center of spiritual culture. [In Ukrainian].

Varela, F., \& Maturana, U. (2001). The tree of of knowledge: The biological roots of human understanding / transl. from English by Y. Danilov. Moscow: Progress - Tradiziya. [In Russian].

Dobronravova, I. (2005). Philosophy of Education in the age of post-non-classic science. Philosophy of Education. (1), 116-125. [In Ukrainian].

Dobronravova, I. (2017). Practical Philosophy of Science. Sumy: Universitetska knyga, [In Ukrainian].

Mamardashvili, M. (1984). Classic and non-clasic ideals of rationality. Tbilisi: Mzenijereba. [In Russian].

Polanyi, M. (1985). Personal Knowledge / transl. from English by V. Lectorsky. Moscow: Progress. [In Russian].

Stepin, V. S. Theoretical knowledge. Moscow: Progress - Tradiziya. [In Russian].

Davis-Seaver, J. (2003). Chaos in the Classroom. INSC 2003. Programme and Abstracts. (7-9 of February Vienna. Austria ), 42.

\section{Iryna Dobronravova. Autopoiesis in online learning}

Conception of autopoiesis has an important place among conceptions of selforganization. Biologists Humberto Maturana and Francisco Varela consider living beings as self-referring and self-constructing autonomous systems, namely, as autopoietic systems. They proclaimed: "All doing is knowing. All knowing is doing" 
in their famous book "The Tree of Knowledge". It concerned all living beings, including human beings with the biological roots of their cognition. Author of the article choose this conception of self-organization as working model of online teaching and learning just because the lack of such biologist roots in online communication. Unconsciousness but influenced features of live communication by humans with their "embodied mind" just loose in communication online. Analyzing own experience of off line and online teaching in frame of autopoietic approach, author tries to seek the means to overcome the restrictions of online teaching and learning. The idea by Maturana and Varela about continually recurrent interactions between participants of doing and knowing which provide their creation of common world in common linguistic field became the main point of conclusion. Active communications between lector and students and between students in workshops can partly compensate an absence of live communication. It means that standard obvious relation between quantity of lectures and workshops have to be changed with free choice by lector among new special forms of online learning. Original work of students for solving the tasks are preferable, especially if the tasks are connected with scientific or technologic researches. In any case supporting the discussions and debates, teachers can stimulate those recurrent interactions which guarantee the autopoiesis as self-construction of common world in which self-organization of young persons is possible in their becoming the young specialists. The concept of autopoiesis is able to maximize the success of communication between teachers and students and students to each other to provide feedback in the joint actions of cognition, creating the effect of sustainable self-organization in learning.

Key words: autopoiesis, learning online, self-organization, communication, selfconstruction, recurrent interactions.

Ірина Добронравова - доктор філософських наук, професор, завідувачка кафедри філософії та методології науки, Київський національний університет імені Тараса Шевченка, Україна.

E-mail: irinadobronravova@knu.ua

https://orcid.org/0000-0002-8767-4045

Iryna Dobronravova - Doctor of Science in Philosophy, Professor, Chief of Chair Philosophy and Methodology of Science, Taras Shevchenko National University of Kyiv, Ukraine.

E-mail: irinadobronravova@knu.ua

https://orcid.org/0000-0002-8767-4045 